Jurnal Akuntansi dan Investasi, Vol. 17 No. 2, Hlm: 132-140, Juli 2016

Artikel ini tersedia di website: http://journal.umy.ac.id/index.php/ai

DOI: 10.18196/jai.2016.0050.132-140

\title{
Mengungkap Fenomena Potongan Angsuran Murabahah di Perbankan Syariah
}

\author{
Yudhy Muhtar Latuconsina* \\ Prodi Akuntansi Universitas Darussalam Ambon, Jl. Waehakila Puncak Wara, Ambon, Maluku, Indonesia
}

\begin{tabular}{|c|}
\hline A RTICLE INFO \\
\hline $\begin{array}{l}\text { Article history: } \\
\text { received1 } 8 \text { Nov } 2015 \\
\text { revised } 27 \text { Mar } 2016 \\
\text { accepted } 8 \text { Apr } 2016\end{array}$ \\
\hline $\begin{array}{l}\text { Keywords: } \\
\text { Murabahah's Discount } \\
\text { Payment; Annuity; } \\
\text { Transcendental } \\
\text { Phenomenology }\end{array}$ \\
\hline
\end{tabular}

\section{ARTICLE INFO}

\section{A B S T R A C T}

The purpose of this study is to unveil te phenomenon of Murabahah's discounting payment in shariah banking. This study using interpretive perspective with transcendental phenomenology as a method. The results show that Murabahah's discounting payment is the appeal of Islamic banking to attract prospective customers murabaha financing. In addition, the major determinant factor of the advantages of being given Murabahah's discounting payment. Because of these factors, the Islamic banking policy set Murabahah's discounting payment is only given to to the customers that will end their payment earlier and it helped to get profit realization of shariah banking. In order to minimize the "loss" of the margin (as a profit of Murabahah's), shariah banking using annuity method in the scheme of Murabahah's payment.

(c) 2016 JAI. All rights reserved

\section{PENDAHULUAN}

Pemberlakuan potongan angsuran murabahah tertuang dalam Pernyataan Standar Akuntansi Keuangan (PSAK) 102 paragraf 26, 27 dan 28. PSAK 102 merupakan pedoman akuntansi untuk transaksi pembiayaan murabahah yang menjadi rujukan bagi seluruh perbankan syariah. Dalam paragraf 26 disebutkan bahwa potongan pelunasan piutang murabahah yang diberikan kepada pembeli yang melunasi tepat waktu atau lebih cepat dari waktu yang disepakati. Menurut Wiroso (2010:113), potongan pembayaran angsuran murabahah dalam PSAK 102 paragraf 26 diberikan atas dasar prestasi yang dilakukan nasabah yang ditunjukan oleh ketepatan waktu pembayaran, pembayaran angsuran lebih cepat atau lebih dahulu dari yang ditetapkan. Dikatakan prestasi karena nasabah melaksanakan tanggungjawabnya untuk melakukan pembayaran angsuran murabahah sesuai dengan kesepakatan awal.

Paragraf 27 dalam PSAK 102 berkaitan dengan metode akuntansi yang digunakan dalam pemberian potongan kepada nasabah (baca: nasabah) yang berkaitan dengan cara perlakuannya. Terdapat dua perlakuan akuntansi, yang pertama diberikan saat pelunasan dengan mengurangi piutang murabahah dan diberikan setelah pelunasan dengan menerima pelunasan kemudian memberikan potongan kepada pembeli. pengakuan, pengungkapan serta penyajian dalam laporan keuangan. Sedangkan substansi paragraf 28 menerangkan tentang pengakuan akuntansi potongan pelunasan angsuran murabahah. Paragraf 28 juga menjelaskan tentang subjek penerima potongan angsuran murabahah yaitu bagi nasabah pembiayaan yang mengalami penurunan kemampuan pembayaran. Dengan demikian, secara garis besar terdapat tiga subjek penerima potongan pembayaran angsuran murabahah yaitu nasabah yang melakukan pelunasan tepat waktu, lebih cepat dari jangka waktu jatuh tempo dan yang mengalami penurunan kemampuan pembayaran angsuran murabahah.

Pemberian potongan angsuran pembayaran murabahah yang diatur dalam PSAK 102 paragraf 26 dan 27 dikuatkan dengan fatwa DSN-MUI Nomor 23/DSN-MUI/III/2002 yang diprioritaskan kepada pelunasan tepat waktu dan lebih awal waktu. Sedangkan untuk paragraf 28 dikuatkan fatwa DSNMUI Nomor 46/DSN-MUI/II/2005 tentang potongan tagihan murabahah. Kedua fatwa merupakan bentuk legalitas syariah terhadap perlakuan pemberian potongan pelunasan. Menurut Wiroso (2011), disamping sebuah bentuk prestasi, kedua fatwa ini dikeluarkan karena pengakuan adanya itikat baik dari nasabah untuk memenuhi kewajibannya sehingga penghargaan layak diberikan kepadanya. Namun dalam kedua fatwa ini, hal penting yang perlu diperhatikan adalah pemberian potongan pelunasan angsuran murabahah tidak boleh diperjanjikan dalam akad sebagai bentuk kesepakatan 
antar nasabah dan perbankan syariah. Kedua fatwa ini juga menegaskan bahwa besaran potongan yang akan diberikan kepada nasabah tergantung dari kebijakan perbankan syariah (Widodo, 2010:50).

Praktek kredit di perbankan konvensional juga terdapat realitas pelunasan di percepat sebagaimana dalam pembiayaan murabahah. Namun, jika pelunasan dipercepat dalam pembayaran angsuran murabahah dimungkinkan akan diberikan kemudahan dalam bentuk potongan angsuran maka lain halnya dengan kredit di perbankan konvensional. Di perbankan konvensional, nasabah yang melakukan pelunasan dipercepat dikenakan sanksi admistrasi atau dengan kata lain dikenai pinalti. Kondisi ini akan terlihat dalam contoh formulir kredit tanpa agunan Bank Mandiri di mana dalam bagian ketentuan umum disebutkan bahwa:

"pelunasan dapat dilakukan sebelum jatuh tempo (sebagian atau seluruhnya) dan akan dikenakan pinalti sebesar 5\% (KTA Mandiri) dan $1 \%$ (Mitrakarya Mandiri) dihitung dari sisa outstading atau sesuai ketentuan bank. Nilai pelunasan sebagian minimal sebesar $10 \%$ dari outstanding kredit”.

Hal serupa juga berlaku di perbankan-perbankan syariah yang lainnya.

Secara logis, menjadi aneh jika pelunasan yang dipercepat diberikan sanksi pinalti atau semacamnya. Seharusnya perbankan konvensional lebih senang jika nasabah kredit melunasi lebih cepat karena keuntungan diperoleh dalam waktu yang lebih pendek dari kesepakatan awal. Namun, ternyata menurut cara berfikir perbankan konvensional berbeda di mana jika pelunasan dipercepat dilakukan maka mereka tidak mendapatkan keuntungan bunga kredit yang bersifat fluktuatif (Arantan:2013). Selain dari kehilangan keuntungan, pelunasan lebih cepat berpotensi memberikan gangguan dalam rencana keuangan yang berisi tentang alokasi hasil dari kredit tersebut. Inilah gambaran realitas tentang jiwa kapitlistik (nilai materialistik) di mana semua kebijakan hanya beroritenasi kepada keuntungan semata.

Berbeda dengan perbankan syariah yang dibangun di atas nilai Islam di mana "pancarannya" akan menyentuh segala bentuk kebijakan di perbankan syariah termasuk dalam permasalahan potongan angsuran murabahah. Tujuan utama perbankan syariah tidak hanya menuju ke arah kearah keuntungan (materi) semata namun ada agenda yang lebih besar dari itu yaitu menjadi lembaga penunjang pemeretaan kesejahteraan rakyat (Amanat UU No 21 tahun 2008). Dimesinya pun tidak hanya bersifat keduniaan akan tetapi menjadi "jembatan" bagi tercapainya tujuan keakhiratan. Dimensi ini yang mempengaruhi interaksi bisnis di perbankan syariah yang tercermin dalam bentuk perilaku islami yang tertuang dalam berbagai kebijakan.

Berkenaan dengan potongan yang diberikan dalam angsuran murabahah, dengan merujuk kepada pondasi nilai islam yang menggerakkan semua kebijakan maka sudah barang tentu kebijakan ini tidak hanya berlatar belakang keuntungan semata akantetapi unsur ibadahnya juga ada. Hal ini beralasan karena nasabah yang mengalami penurunan dalam kemampuan membayar memiliki peluang untuk mendapatkan kemudahan berupa potongan angsuran. Artinya, ada aspek tolong-menolong yang mencirikan nilai-nilai islam yang terimplementasi dalam kebijakan di perbankan syariah. Namun, perlu juga dibuktikan melalui penelitian empiris untuk memahami dan memaknai lebih mendalam tentang realitas sesungguhnya dari kebijakan pemberian potongan angsuran murabahah di perbankan syariah. Sepengetahuan peneliti, belum ada penelitian yang membahas tentang potongan angsuran murabahah di perbankan syariah.

Berlatarbelakang kondisi di atas, maka penelitian ini dilakukan untuk mengungkap fenomena pemberian potongan angsuran murabahah di perbankan syariah. Untuk melakukan pengungkapan lebih mendalam maka digunakanlah penelitian kualitatif interpretif dengan metode analisisnya adalah fenomenologi transendental. Hasil penelitian ini diharapkan mampu memberikan gambaran realitas sesungguhnya tentang pemberian potongan angsuran murabahah yang dapat digunakan sebagai referensi praktis maupun teoritis bagi praktisi perbankan syariah, DSAK-syariah, DSN-MUI, pemerintah, calon nasabah perbankan syariah baik dari masyarakat muslim maupun masyarakat pada umumnya.

\section{TINJAUAN LITERATUR DAN FOKUS PENELITIAN}

Pembiayaan murabahah merupakan salah satu model pembiayaan di perbankan syariah yang menggunakan konsep jual-beli. Definisi murabahah sebagaimana tertera di dalam PSAK 102 adalah menjual barang dengan harga jual sebesar harga perolehan ditambah keuntungan yang disepakati dan penjual harus mengungkapkan harga perolehan barang tersebut kepada pembeli. Menurut Widodo (2010) pengertian diatas mengarah pada satu karakteristik fundamental murabahah yaitu adanya transparansi terhadap harga perolehan barang ditambah sejumlah laba yang besarnya sesuai dengan kesepakatan antara penjual dan pembeli atau dengan kata lain dilakukan atas dasar cost-plus profit. 
Pembiayaan murabahah yang dipraktekkan di perbankan syariah saat ini adalah jenis pembiayaan berdasarkan pesanan yang bersifat mengikat serta menggunakan cara pembayaran angsuran atau cicilan (Rahmawaty, 2007). Pembayaran angsuran atau cicilan adalah pembayaran yang dilakukan kemudian setelah penyerahan barang baik secara tangguh sekaligus dibelakang atau secara angsuran. Bahasa konvensionalnya adalah cicilan kredit. Nominal angsuran ditentukan oleh besaran pembiayaan dan lamanya waktu pelunasannya.

Sebagaimana kredit di perbankan non-syariah, pembiayaan murabahah di perbankan syariah juga mendapati realitas yang sama yaitu macetnya pembayaran angsuran. Jika di kredit ada penalti karena ketidakmampuan membayar maka di perbankan syariah tidaklah demikian karena terdapat lembaga syariah yang mengatur hal tersebut yaitu lembaga fatwa Dewan Standar Nasional (DSN)- Majelis Ulama Indonesia. Ada aturan islam yang bersifat humanis-harmonis karena hubungan yang dibangun oleh nasabah dan perbankan syariah adalah hubungan kekeluargaan

Kebalikan dari macetnya pembayaran angsuran, jika nasabah melakukan pembayaran angsuran tepat pada waktunya atau bahkan lebih cepat dari jatuh temponya maka dimungkinkan akan diberikan penghargaan berupa potongan angsuran oleh perbankan syariah. Potongan tersebut akan memberikan keutungan kepada nasabah karena besaran angsuran yang dibayarkan telah berkurang. Ini juga yang membedakan antara bank syariah dan bank non-syariah.

Pernyataan Standar Akuntansi Keuangan (PSAK) 102 tentang akuntansi murabahah dalam paragraf 26 sampai dengan 28 menjabarkan tentang adanya potongan angsuran tersebut. Paragraf 26 menyatakan bahwa potongan pelunasan piutang murabahah yang diberikan kepada pembeli yang melunasi secara tepat waktu atau lebih cepat dari waktu yang disepakati diakui sebagai pengurang keuntungan murabahah. Paragaraf ini menjelaskan tentang potongan yang diberikan karena nasabah melakukan percepatan pelunasan angsuran.

Paragraf 27 menjelaskan tentang metode pemberian potongan pelunasan piutang murabahah. Paragraf tersebut menjelaskan bahwa pemberian potongan pelunasan piutang murabahah dapat dilakukan dengan menggunakan salah satu metode yaitu: (1) diberikan pada saat pelunasan di mana penjual mengurangi piutang murabahah dan keuntungan murabahah; atau (2) diberikan setelah pelunasan, yaitu penjual menerima pelunasan piutang dari pembeli dan kemudian membayarkan potongan pelunasannya kepada pembeli. Sedangkan pada paragraph 28 menjelaskan tentang pengakuan poto- ngan tersebut yaitu: (1) jika disebabkan oleh pembeli yang membayar secara tepat waktu, maka diakui sebagai pengurang keuntungan murabahah; (2) jika disebabkan oleh penurunan kemampuan pembayaran pembeli, maka diakui sebagai beban.

Ketiga Paragraf di PSAK 102 menekankan pada 3 kondisi pemberian potongan yaitu (1) pelunasan tepat pada waktunya, (2) Pelunasan lebih cepat dari waktu yang disepakati (3) Penurunan kemampuan pembayaran pembeli. Pemberian potongan angsuran murabahah kepada dua kondisi (1 dan 2) merupakan bentuk penghargaan perbankan syariah atas prestasi nasabah untuk memenuhi tanggungjawabnya sesuai kesepakatan bersama (Wiroso, 2010:113). Sedangkan kondisi yang terakhir lebih mengarah kepada bentuk keringanan sebagai upaya mengimplementasikan nilai-nilai Islam, sebagaimana Firman Allah dalam surah Al-Baqarah ayat 280 bahwa”... dan jika (orang berutang itu) dalam kesukaran, maka berilah tangguhan sampai dia berkelapangan. Dan menyedekahkan (sebagian atau semua utang) itu lebih bik bagimu, jika kamu mengetahui." (Fatwa No.23/DSN-MUI/III/2002).

Ketiga kondisi ini ditopang oleh fatwa DSNMUI nomor 23 tahun 2002 tentang potongan pelunasan dalam murabahah dan nomor 46 tahun 2005 tentang potongan tagihan murabahah. Fatwa DSNMUI nomor 23 tahun 2002 menyatakan bahwa (1) jika nasabah melakukan pelunasan pembayaran tepat waktu atau lebih cepat dari waktu yang telah disepakati, LKS boleh memberikan potongan dari kewajiban pembayaran tersebut, dengan syarat tidak diperjanjikan dalam akad dan (2) Besar potongan sebagaimana dimaksud di atas diserahkan pada kebijakan dan pertimbangan LKS. Sedangkan fatwa DSN-MUI Nomor 46 tahun 2005 menyatakan bahwa pemberian potongan tagihan murabahah dapat diberikan dengan ketentuan (1) LKS boleh memberikan potongan dari total kewajiban pembayaran kepada nasabah dalam transakasi (akad) murabahah yang telah melakukan kewajiban pembayaran cicilan dengan tepat waktu dan nasabah yang mengalami penurunan kemampuan pembayaran. (2) Besar potongan sebagaimana dimaksud di atas diserahkan pada kebijakan LKS. (3) Pemberian potongan tidak boleh diperjanjikan dalam akad.

Perlu di tegaskan kembali bahwa berdasarkan substansi paragraf 26 dan 27 PSAK 102, potongan yang diberikan kepada nasabah adalah potongan pada saat pelunasan, sedangkan paragraph 28 menggambarkan tentang kondisi pada saat penagihan pembayaran angsuran. Untuk nasabah yang melakukan pembayaran angsuran tepat pada waktu dapat diberlakukan dua potongan yaitu pada saat pelunasan dan pembayaran angsuran murabahah. Hal ini 
juga dapat dilihat pada fatwa-fatwa DSN-MUI yang menopangnya.

Berdasarkan penjelasan fatwa DSN-MUI di atas diperoleh informasi bahwa besaran potongan yang diberikan atas ketiga kondisi tersebut di serahkan sepenuhnya kepada kebijakan perbankan syariah. Artinya, berapapun besaran potongan yang diberikan tergantung kepada perbankan syariah itu sendiri. Bahkan terdapat di dua kemungkinan yaitu dapat diberikan potongan dan tidak diberikannya potongan karena terlihat jelas dari kata "boleh memberikan potongan sebagaimana keterangan fatwa DSN-MUI di atas. Dengan demikian, potongan-potongan tersebut dihukumi sunnah atau wajib dilakukan.

Penjabaran teoritis di atas memberikan daya tarik yang besar untuk melihat gambaran realitas dan pengungkapan lebih mendalam tentang fenomena angsuran murabahah di perbankan syariah. Sejauh pengetahunan peneliti, belum pernah menemukan penelitian-penelitian yang membahas tentang potongan angsuran murabahah di perbankan syariah Dengan demikian, fenomena itu sangat layak untuk diteliti dengan berfokus kepada pemberian potongan angsuran murabahah di perbankan syariah. Berangkat dari fenomena ini maka sudah selayaknya penelitian ini dilakukan dengan mengangkat sebuah rumusan masalah sebagai berikut:

RM: Bagaimana makna dibalik pemberian potongan angsuran murabahah di perbankan syariah?

\section{METODE PENELITIAN}

Metode penelitian yang digunakan adalah metode kualitatif dengan landasarn paradigmanya adalah interpretif dan fenomenologi transendental sebagai pendekatan penelitian. Prastowo (2012) mengartikan penelitian kualitatif sebagai penelitian yang bermaksud untuk memahami fenomena apa yang dialami oleh subjek penelitian misalnya perilaku, persepsi, motivasi, tindakan dan lain sebagainya secara holistik dan dengan cara deskripsi dalam bentuk kata-kata dan bahasa, pada suatu konteks khusus yang alami dan dengan memanfaatkan berbagai metode alamiah (lihat juga: Abdurahim, 2014; Tumirin da Abdurahim, 2015; Mamulati et al., 2016). Penelitian kualitatif yang sering disebut juga dengan penelitian naturalistik karena penelitiannya dilakukan pada kondisi yang alamiah (natural setting) (Sutopo, 2002; Rahmanti, 2012).

Landasan penelitian ini menggunakan paradigma interpretif. Burrell dan Morgan (1979) menjelaskan bahwa paradigma interpretif meliputi cakupan yang laus atas gagasan filosofis dan sosiologi yang memberikan karakteristik umum untuk mencoba memahami dan menjelaskan dunia sosial dengan tujuan utama untuk melihat pelaku yang secara langsung terlibat dalam proses sosial. Menurut Audifax (2008), paradigma interpretif menjelaskan mengenai bagaimana keberadaan manusia dalam mengiterpretasi dan merasakan realitas. Triyuwono (2009) juga menjelaskan bahwa paradigma interpretif tidak digunakan dalam rangka untuk menjelaskan (to explain) dan meramalkan (to predict), melainkan untuk memaknai (to interpret atau to understand) realitas sosial.

Metode penelitian yang digunakan dalam penelitian ini adalah fenomenologi transendental. Fenomenologi transendental dalam penelitian ini adalah model Edmurt Husserl.Fenomenologi transendental Husserl mengadopsi pola berfilsafat Kant, yaitu filsafat transendental. Filsafat transendental Kant menggali akar transsendental pengetahuan manusia sampai membentuk ego transendental, sebuah ego yang berkesinambungan dan tunggal sebagai syarat kesatuan pengetahuan manusia. Berdasarkan pola berfilsafat transendental, fenomenologi menurut Husserl harus mengeksplorasi bukan hanya struktur esensial kesadaran, melainkan juga keberakaran mereka pada ranah transendental dan juga ego transendental sebagai sumber absolut (Adian, 2010). Husserl percaya bahwa "inti usaha fenomenologi" adalah untuk memurnikan sikap alamiah kehidupan sehari-hari dengan tujuan menerjemahkannya sebagai sebuah objek untuk penelitian filsafat secara cermat dan dalam rangka menggambarkan serta memperhitungkan struktur esensialnya” (Natanso, 1966 dalam Ardianto dan Anees, 2007).

Husserl memformulasikan fenomenologi sebagai studi mengenai struktur kesadaran yang mampu mereferensikan objek-objek di luar kesadaran itu sendiri. Fenomena yang tampak sebenarnya adalah refleksi realitas yang tidak berdiri sendiri karena apa yang tampak adalah objek yang penuh makna transendental. Agar seorang peneliti mendapatkan hakikat kebenaran, maka harus menerobos melampaui fenomena yang tampak. Dengan demikian, fenomena yang tampak oleh individu merupakan refleksi dari pengalaman transendental dan pemahaman tentang makna (Audivax, 2008). Menurut Husserl, dengan fenomenologi manusia dapat mempelajari bentuk-bentuk pengalaman dari sudut pandang orang yang mengalaminya secara langsung, seolah-olah peneliti yang mengalaminya sendiri (Kuswarno, 2009). Lebih lanjut menurutnya, struktur kesadaran dalam pengalaman ini yang pada akhirnya membuat makna dan menentukan isi dari pengalaman (content of experence). 
Husserl memberikan sumbangan metodis itu kepada filsafat, yakni epoche. Epoche sendiri adalah penundaan semua asumsi tentang kenyataan demi memunculkan esensi (Adian, 2010). Menurut Kuswarno (2009), epoche merupakan pemutus hubungan dengan pengalaman dan pengetahuan yang kita miliki sebelumnya. Lebih lanjut Husserl menjelaskan bahwa metode ini meliputi pemberian tanda kurung (bracketing) atau menundai sikap alamiah dari halhal kehidupan yang diterima begitu saja dalam rangka memperoleh pemahaman yang lebih murni dari fenomena yang diinvestigasi. Selanjutnya, dilakukan reduksi fenomenologi dengan menghadirkan kembali penilaian, prasangka dan pandangan-pandangan di sekitar fenomena. Reduksi fenomenologi merupakan proses abstraksi esensi kesadaran menggunakan intuisi atau refleksi. Tahap ini merupakan akhir dari proses fenomenologi transcendental yang menghasilkan esensi murni yang universal atau menjadikan realitas sebagai intisari dari realitas itu sendiri.

Informan dalam penelitian ini adalah aktor di perbankan syariah yang terlibat dalam seluk-beluk pembiayaan murabahah. Konsentrasi dalam pembiayaan murabahah diarahkan kepada kebijakan pemberian potongan pembayaran angsuransehingga diharapkan para informan memiliki pengetahuan yang mendalam terkait fokus tersebut. Adapun daftar informan antara lain Bapak HM dari Bank Muamalat Malang, Bapak PD dari Bank Tabungan Negara Syariah Malang, Ibu MT dari Bank Syariah Mandiri.dan ketiganya merupakan aktor dalam transaksi pembiayaan murabahah di perbankan syariah. Walaupun hanya menjadi pelaksana SOP bank syariah akan tetapi ketiga informan ini merupakan "pintu pertama" kebijakan pemberian potongan pelunasan angsuran murabahah. Artinya,mereka juga dapat bertindak sebagai penentu awal bahkan dapat juga menjadi penentu akhir sehingga layak dijadikan sebagai informan.

\section{HASIL DAN PEMBAHASAN}

\section{Potongan Angsuran Murabahah Sebagai Daya Tarik Bank Syariah}

Sebagaimana yang diketahui bahwa pemberian potongan diterapkan kepada nasabah yang melakukan pelunasan tepat waktu, lebih awal dan karena penurunan kemampuan membayar angsuran sebagaimana tertuang dalam PSAK 102 paragraf 26, 27 dan 28 dan dikuatkan oleh fatwa DSN-MUI. Kondisi pelunasan lebih awal dari jangka waktu jatuh tempo yang diimplementasikan di bank Muamalat sebagaimana dijelaskan oleh Bapak HM sebagai berikut:

"Kalau mau pelunasan lebih cepat misalkan jangka waktunya 10 tahun, 2 tahun sudah berjalan kan tinggal 8 tahun, ditahun ketiga ini misalkan sisa hutang nasabah sekarang tinggal 100 juta, misalkan mas sekarang sudah ada uang 100 juta nih, mau ditutup pembiayaan saya, boleh.”

Contoh pelunasan di percepat juga disampaikan oleh Ibu MT bahwa :

"Contoh pelunasan dipercepat adalah, misalnya nasabah membayar untuk jangka waktu 5 tahun tapi dalam jangka waktu 3 tahun dia punya rezeki untuk melunasi."

Realitas ini pun terjadi di bank syariah yang dinaungi bapak PD di mana beliau menyatakan bahwa:

"Pada perjalanannya, misalnya nasabah ambil 10 tahun. Tapi realitanya jarang dibayar 10 tahun, ratarata 2,3 atau 5,6 tahun sudah dilunasi.”

Penjelasan informan di atas memberikan gambaran bentuk pelunasan lebih awal untuk mendapatkan potongan pembayaran angsuran murabahah. Pelunasan lebih awal tidak membatasi waktu percepatannya. Artinya, nasabah dapat melakukan percepatan pelunasan sesuai dengan keinginan mereka. Misalnya berdasarkan keterangan informan di atas, pelunasan dapat dilakukan di tahun ketiga dalam jangka waktu 10 tahun pembayaran atau bahkan di awal-awal waktu angsuran sesuai dengan kemampuan nasabah.

Penjelasan informan di atas juga menunjukkan bahwa pelunasan lebih awal yang dilakukan sebelum waktu jatuh tempo merupakan kejadian yang sering terjadi dalam pembiayaan murabahah di perbankan syariah. Hal ini berkaitan dengan kemampuan finansial yang dimiliki oleh nasabah pembiayaan murabahah. Semakin besar kemampuan finansial nasabah semakin besar peluang pelunasan lebih awal akan terjadi. Biasanya, nasabah yang sering melakukan pelunasan lebih awal di dominasi oleh para pedagang atau wirausahawan sebagaimana yang disampaikan oleh bapak PD bahwa:

\footnotetext{
"Memang menguntungkan terutama bagi nasabah yang pedagang atau wirausaha dimana dapat untungnya cepat tapi kalau dia karyawan, menguntungkannya dalam jangka panjang“.
}

Pelunasan lebih awal dari jangka waktu jatuh tempo memberikan keuntungan bagi nasabah. Keu- 
ntungan inilah menjadikan nasabah sering melakukan pelunasan lebih awal dalam angsuran pembiayaan murabahah-nya. Keuntungan tersebut berupa potongan angsuran murabahah. Potongan angsuran pembayaran murabahah memberikan keringanan kepada nasabah dalam upaya menyelesaikan kewajibannya. Semakin besar potonganyang diberikan kepada nasabah maka semakin kecil beban pembayaran angsuran murabahahnya dan ini merupakan bentuk kepedulian perbankan syariah terhadap mereka.

Potongan angsuran murabahah yang diberikan lebih berorientasi kepada syarat pelunasan lebih awal sedangkan dua kondisi lainnya (pelunasan tepat waktu dan penurunan kemampuan membayar) tidak menjadi syarat kebijakan tersebut. Alasan utama sebagaimana ulasan teoritis adalah karena pelunasan lebih awal dianggap sebagai prestasi nasabah atas pemenuhan kewajibannya. Dalam kenyataannya, anggapan prestasi lebih mengarah kepada upaya untuk menarik lebih banyak nasabah pembiayaan murabahah. Hal ini terlihat dari ucapan Ibu MT bahwa:

"Kalau di bank lain, kredit 5 tahun trus dia mau menutupi 1,2,3,4 atau 5 tahun tetap bayar semuanya 5 tahun sampai lunas nanti kemudian diberikan potongan 5 atau 6 bulan untuk marginnya sedangkan kalau di BSM cuma membayar pokok dan 2 kali margin ditambah biaya administrasi.”

Pernyataan informan ini menunjukkan adanya upaya membandingkan antara bank syariahnya dengan bank syariah yang lain. Dengan jumlah potongan yang lebih besar dari bank syariah lainnyamaka akan menjadi daya tarik bagi nasabah yang akan melakukan pembiayaan murabahah. Ucapan informan yang didukung oleh perilakunya menyerupai "ajakan" untuk memilih bank syariahnnya. Di lain sisi, potongan angsuran murabahah sebagai "daya tarik" pembiayaan murabahah juga dituangkan dalam bentuk akad, walaupun hakekatnya tidak diperbolehkan oleh DSN-MUI. Namun dengan polesan "kata" untuk menutupi makna, tindakan itupun dilakukan. Dalam akad tersebut tertulis bahwa:

"Dalam hal nasabah melakukan pelunasan dipercepat, bank dimungkinkan dapat memberikan potongan dari kewajiban pembayaran”

Kata “dimungkinkan” menunjukkan adanya pemberian potongan angsuran murabahah atas pelunasan dipercepat yang dilakukan oleh nasabah. Bahkan, realitasnya bukan hanya dimungkinkan akan tetapi benar-benar akan diberikan kepada nasabah.
Seperti yang disampaikan oleh bank syariah pemilik akad tersebut yaitu:

"Pelunasannya itu adalah pokok ditambah 1 kali margin..."

Rumusan yang disampaikan oleh informan di atas juga menunjukkan bahwa pemberian potongan telah tersistem secara otomatis. Pelunasan yang dipercepat dengan jangka waktu tertentu, tetap akandikenakan kebijakan pokok di tambah 1 kali margin. Tersistemnya pemberian potongan angsuran murabahah terlihat juga pada pernyataan informan pada bank syariah sebelumnya (BSM) sehingga dapat dikatakan bahwa potongan ini merupakan hal yang menarik untuk disampaikan kepada calon nasabah atau target pembiayaan murabahah.

Informasi tentang pemberian potongan angsuran murabahah atas pelunasan dipercepat yang dilakukan oleh nasabah merupakan "senjata pemikat” bank syariah khususnya marketing staff yang bertugas mencari maupun melayani calon nasabah pembiayaan murabahah. Melalui informasi pemberian potongan angsuran dengan syarat pelunasan dipercepat yang dilakukan di awal pertemuan atau perkenalan pembiayaan murabahah mampu mempengaruhi keputusan nasabah untuk melakukan transaksi tersebut di bank syariah yang didatanginya. Selain potongan tersebut, hal yang menjadi daya tarik juga adalah besaran margin sehingga kebijakan ini menjadi pelengkap daya tarik pembiayaan murabahah di bank syariah tersebut.

Akhirnya, potongan angsuran murabahah yang diberikan kepada nasabah pembiayaan yang melakukan pelunasan angsuran dipercepat bukan hanya sebagai apresiasi atas prestasi nasabah untuk memenuhi tanggungjawabnya akantetapi menjadi ajang promosi atau daya pikat pembiayaan murabahah di bank syariah.

\section{Keuntungan; Penentu Kebijakan Pemberian Potongan Angsuran Murabahah}

Penjabaran melalui pernyataan informan di atas memberikan gambaran realitas tentang implementasi pemberian potongan angsuran murabahah di perbankan syariah. Berdasarkan landasan teoritis sebagaimana tertuang dalam PSAK 102 paragraf 26, 27 dan 28 serta dukungan dari DSN-MUI, diketahui bahwa terdapat tiga kondisi yang memungkinkan diberikannya potongan angsuran murabahah. Yang pertama adalah dikarenakan nasabah melakukan pelunasan lebih awal dari jangka waktu jatuh temponya. Yang kedua adalah nasabah melakukan pelunasan tepat pada waktunya dan yang ketiga 
adalah nasabah dalam kondisi penurunan kemampuan pembayaran angsuran. Namun, dalam implementasinya, yang mendapatkan potongan angsuran murabahah adalah nasabah yang melakukan pelunasan lebih awal.

Pelunasan lebih awal memberikan keuntungan yang lebih cepat dibandingkan dengan dua kondisi lainnya. Keuntungan yang direncanakan diperoleh dalam jangka waktu 10 tahun dapat terealisasi dalam waktu yang lebih cepat, semisal tahun kelima atau yang lainnya. Keuntungan tersebut dapat digunakan sebagai modal untuk melakukan transaksi pembiayaan murabahah atau dialokasikan untuk keperluan lain yang ada di perbankan syariah.

Pelunasan tepat waktunya walaupun merupakan bentuk prestasi dalam penyelesaikan pembayaran angsuran murabahah serta menunjukkan itikad yang baik sebagaimana pernyataan DSN-MUI akantetapi bukan menjadi syarat untuk diberikannya potongan angsuran murabahah. Kondisi ini dianggap sesuatu yang "wajar" dan tidak memberikan "efek positif" yang signifikan kepada perbankan syariah. Apalagi dengan nasabah yang mengalami penurunan kemampuan pembayaran angsuran, sudah barang tentu tidak akan mendapatkan potongan atas angsuran tagihan maupun pelunasan murabahahnya.

Penurunan kemampuan membayaran angsuran murabahah memiliki prosedur lain di perbankan syariah. Dalam keterlambatan pembayaran ( PSAK 102 paragraf 29 disebutkan bahwa:

"Denda dikenakan jika pembeli lalai dalam melakukan kewajibannya sesuai dengan akad, dan denda yang diterima diakui sebagai bagian dana kebajikan”.

Aturan ini juga didukung dengan Fatwa DSN-MUI No 17/DSN-MUI/IX/2000. Artinya bahwa, setiap nasabah yang terlambat dalam membayar angsuran murabahah sesuai dengan waktu yang disepakati dalam akad maka akan dikenakan denda walaupun dengan syarat "jika lalai" namun realitasnya tetap dikenai sanksi tersebut. Jika nasabah tidak mampu menyelesaikan pembayaran angsurannya maka dilakukan perpanjangan jangka waktu pembayaran hutang nasabah sebagai bentuk kelonggaran baginya. Inipun diatur dalam $\mathrm{f}$ atwa Dewan Syariah Nasional No 4 tentang penundaan pembayaran dalam murabahah jika nasabah sudah tidak mampu membayar hutangnya. Namun, apabila nasabah benar-benar tidak mampu menyelesaikan hutangnya maka alternatif terakhir yang dilakukan adalah menjual (bukan mengambil-alih) agunan miliki nasabah di mana hasil penjualan akan dipergunakan untuk membayar hutangnya (Wiroso, 2011). Penjelasan ini sejalan dengan apa yang disampaikan oleh Bapak HM yang menyatakan bahwa :
"Kalau misalkan nasabah ini sudah menyerah, angkat tangan, sudah tidak mampu untuk membayar dengan jangka waktu sekian bulan itu biasa masuk pelelangan.”

Penjabaran di atas menjelaskan tentang kedua kondisi yang "terhempas" dari katagori kebijakan pemberian potongan angsuran murabahah. Hal ini dikarenakan kedua kondisi tersebut akan mempengaruhi perolehan keuntungan yang didapatkan oleh bank syariah. Artinya, faktor keuntungan menjadi pertimbangan yang kuat untuk menetapkan kebijakan pemberian potongan angsuran murabahah di perbankan syariah. Keuntungan menjadi faktor utama diberikannya potongan tersebut, sebagaimana dijelaskan oleh Bapak HM bahwa:

"Intinya bank itu menjual jasa untuk mencari keuntungan jadi kita lihat-lihat dulu kondisi dan situasi, misalkan 50\% dirasa cukup untuk memperoleh keuntungan ya sudah.”

Pernyataan di atas juga mengindikasikan bahwa, untuk menetapkan kebijakan tersebut, perbankan syariah melakukan proses analisis agar mendapatkan kejelasan tentang berapa besar potongan yang tepat untuk diberikan kepada nasabah. Keuntungan yang diperoleh dari pembiayaan murabahah menjadi salah satu penentu besarnya potongan yang diberikan kepada nasabah. Walaupun telah tersistem akan tetapi, proses analisi tetap berjalan untuk memastikan besaran keuntungan dari pembiayaan murabahah yang diperoleh bank syariah. Artinya, bank syariah tidak mau terlalu "rugi" atas keuntungan yang diperoleh dari pembiayaan murabahah sehingga diperlukan analisa keuntungan yang mendalam.

Upaya meminimalisir "kerugian" atas keuntungan pembiayaan murabahah yang dikarenakan pemberian potongan angsuran kepada nasabah yang melakukan pelunasan lebih awal didukung juga oleh metode pembayaran angsurannya. Metode pembayaran angsuran yang digunakan adalah anuitas. Rumusan metode anuitas iniditetapkan dengan komposisi angsuran pokok lebih kecil di awal dan akan semakin besar sampai akhir pelunasan. Sebaliknya, margin akan lebih besar di awal dan lebih kecil pada akhir pelunasan. Sistem anuitas dijelaskan oleh Bapak HM bahwa:

\footnotetext{
"Yang bank pake itu sistem anuitas (peneliti: apakah aturan dan BI atau bank sendiri?). itu dari bank sendiri, itu seperti piramida terbalik, biasanya pokok kecil dan margin besar di awal, semakin lama margin semakin kecil sedangkan pokoknya semakin besar tapi jumlah angsuran tetap setiap bulannya, kenapa begitu? itu salah satu cara untuk metigasi resiko, nasabah sewaktu-waktu macet dari pihak
} 
bank masih mendapat keuntungan, dia sudah dapat memperoleh margin yang cukup besar tapi outstanding tetap dibayar".

Sebagimana yang terlihat dalam uraian informan ini, prinsip anuitas dapat digambarkan seperti piramida terbalik. Susunan angsuran yang dibayarkan dengan komposisi margin besar diawal dan semakin kecil diakhir sedangkan pokok angsuran berbanding terbalik yaitu kecil diawal dan semakin besar diakhir. Besaran angsuran tetap sama akan tetapi yang berbeda adalah komposisinya. Penggunaan metode anuitas memberikan kepastian keuntungan bagi perbankan syariah lebih awal. Artinya, dalam perjalanan mengangsur, keuntungan dari margin telah diperoleh sejak pertama kali pembayaran dan semakin berkurang disetiap bulannya. Jika nasabah melakukan pelunasan lebih awal diakhir periode angsuran maka pada hakekatnya potongan margin yang diberikan hanya sedikit. Hubungan ini dijelaskan oleh bapa Pandu bahwa:

"Dulu, angsuran 2 juta, margin dan pokok ini kan 1 juta dan 1 juta tapi tetap marginnya gak berubah, sekarang bank syariah itu seperti ini (menggambarkan metode anuitas) sejak tahun 2008, otomatis dari sudut pandang bank jelas lebih cepat untung, seandainya dilunasi disini (awal pembayaran) nasabah untung, kalau dilunasi ditengah-tengah masih sama-sama untung, kalau dilunasi disini (akhir angsuran) nasabah sedikit dirugikan.”

Penjelasan informan di atas menunjukkan perjalanan histori penentuan metode angsuran di mana sebelumnya menggunakan metode flat dengan komposisi seimbang antara pokok dan margin murabahah. Seiring perkembangan perbankan syariah maka motode ini diganti dengan metode anuitas yang memberikan keuntungan lebih awal kepada mereka. Penggunaan metode flat berpengaruh terhadap pemberian potongan angsuran murabahah karena margin yang dijadikan sebagai objek potongan masih lebih besar sehingga penggunaan metode anuitas juga bertujuan untuk memetigasi resiko dimana keuntungan perbankan syariah dapat terpenuhi.

Penggunaan metode anuitas juga menunjukkan bahwa perbankan syariah merasa "risih" karena keuntungannya terkurangi. Artinya, secara jelas terlihat perbankan syariah tidak sepenuhnya ikhlas untuk memberikan keuntungan kepada nasabah. Kalaupun keuntungan itu diberikan namun bisa jadi hanya sedikit. Kebalikannya, perbankan syariah ingin memaksimalkan keuntungannya dalam kondisi apapun.
Akhirnya, penjabaran di atas memengungkap secara mendalam bagaimana faktor keuntungan menjadi tolak ukur kebijakan pemberian potongan angsuran murabahah. Pelunasan yang dipercepat memberikan keuntungan kepada bank syariah karena mempercepat perolehan keuntungan bagi mereka. Untuk meminimalisir "kerugian" karena pemberian potongan tersebut, bank syariah menggunakan metode anuitas dalam pembayaran angsuran sehingga pada hakikatnya margin sebagian objek potongan hanya Dengan demikian, terlihat jelas bahwakeuntungan tetap menjadi orientasi atau prasyarat utama dalam kebijakan pemberian potongan angsuran murabahah di perbankan syariah.

\section{SIMPULAN}

Penelusuran lebih mendalam menunjukkan bahwa pemberian potongan angsuran murabahah merupakan daya tarik yang digunakan untuk mengikat calon nasabah yang akan melakukan transaksi pembiayaan di bank syariah. Potongan tersebut diberikan kepada nasabah pembiayaan murabahah dengan syarat melakukan pelunasan lebih awal dari jangka waktu jatuh temponya. Hal ini dikarenakan nasabah tersebut membantu mempercepat realisasi keuntungan perbankan syariah dari pembiayaan murabahah. Dua kondisi lainnya yaitu pelunasan tepat waktu dan penurunan kemampuan membayar nasabah tidak diterapkan karena tidak memberikan keuntungan bagi perbankan syariah. Potongan angsuran murabahah akan mengurangi keuntungan yang diperoleh perbankan syariah. Untuk mengurangi resiko "kerugian" atas keuntungan dari pembiayaan murabahah maka perbankan syariah menggunakan metode anuitas untuk sistem pembayaran angsurannya. Penggunaan metode ini juga menunjukkan bahwa perbankan syariah masih "berat" untuk melepaskan keuntungannya kepada nasabah walaupun disisi lain mendapat perolehan keuntungan lebih cepat.

\section{DAFTAR PUSTAKA}

Abdurahim, A. 2014. Oksidentalisme Dalam Perbankan Syariah. Jurnal Akuntansi Multiparadigma, 4 (1), 14-25.

Adian, D. G. 2010. Pengantar Fenomenologi. Depok: Penerbit Koekoesan.

Ardianto, E. dan Q. A. Bambang. 2007. Filsafat Ilmu Komunikasi. Bandung: Simbiosa Rekatama Media. 
Aratan. 2013. Mau mempercepat pelunasan kredit kenapa kena penalty https://arantan.wordpress.com/. Diakses September 2015

Audifax. 2008. ReSearch: Sebuah Pengantar Untuk "Mencari Ulang" Metode Penelitian dalam Psikologi. Yogyakarta: Jalasutra.

Burrell, G. dan Morgan. 1979. Sociological Paradigma and Organizational Analaysis. Elements of the sociology of corporate. By Arena.

DSN-MUI. 2005. Fatwa Dewan Syari'ah Nasional No. 46/DSN-MUI/II/2005 tentang Potongan Tagihan Murabahah (khashm fi almurabahah). Jakarta

DSN-MUI. 2002. Fatwa Nomor 23/DSNMUI/III/2002 tentang potongan pelunasan dalam murabahah. Jakarta

Ikatan Akuntan Indonesia. 2007. Pernyataan standar akuntansi keuangan 102, Akuntansi murabahah. Dewan Standar Akuntansi Keuangan Ikatan Akuntan Indonesia. Jakarta.

Kuswarno, E. 2009. Metodologi Penelitian Komunikasi "Fenomenologi" Konsepsi, Pedo-man dan Contoh Penelitian. Bandung: Widya Padjajaran.

Mamulati, I., I. Triyuwono dan A. D. Mulawarman. 2016. Fenomenologi Sumber Daya Manusia Sebagai Aset Intelektual Dalam Amal Usaha
Muhammadiyah. Jurnal Akuntansi dan Investasi, 17 (1), 93-103.

Prastowo, A. 2012. Metode Penelitian Kualitatif Dalam Perspektif Rancangan Penelitian. Jogjakarta: Ar Ruzz Media.

Rahmanti, V. N. 2012. Sebuah Kajian Mengapa Akuntansi Syariah Masih Sulit Tumbuh Subur di Indonesia. Jurnal Akuntansi dan Investasi, 13 (2), 161-179.

Rahmawaty, A. 2007. Ekonomi Syariah: Tinjauan Kritis Produk Murabahah dalam Perbankan Syariah di Indonesia. La-Riba: Jurnal Ekonomi Islam, 1 (2), 187-203.

Sutopo, H. B. 2002. Metodologi Penelitian Kualitatif; Dasar Teori dan Terapannya dalam Penelitian. Surakarta: Sebelas Maret University Press.

Triyuwono, I. 2009. Perspektif, metodologi, dan Teori Akuntansi Syariah. Jakarta: Rajawali Pers.

Tumirin, T. dan A. Abdurahim. 2015. Makna Biaya Dalam Upacara Rambu Solo. Jurnal Akuntansi Multiparadigma, 6 (2), 175-184.

Widodo, S. 2010. Seluk BelukJual Beli Murabahah, Prespektif Aplikatif. Yogyakarta: Asgard Chapter.

Wiroso. 2010. Akuntansi Transaksi Syariah. Jakarta: Ikatan Akuntan Indonesia. 